\title{
Recovering Lost Moral Ground: Can Walt Make Amends?
}

\author{
James Edwin Mahon and Joseph Mahon
}

Is it possible to recover lost moral ground? In the closing episodes of Breaking Bad it becomes clear that Walter White believes that the correct answer to this question is an affirmative one. Walt believes that he can, and that he has, recovered lost moral ground.

Breaking Bad may be said to explore two distinct and incompatible ways of attempting to recover lost moral ground. The first way is revisionist. This is to rewrite the script of what, morally speaking, has occurred, so that it appears that nothing wrong was done. Since no moral ground has been lost, there is no moral ground to recover. The second way is restorative. This is to admit to morally wrongful behavior, but to attempt to make amends for it. While we concede that it is possible to recover lost moral ground in both of these ways, we deny that Walt is able to do so in both of these ways. At best, Walt can only hope to recover lost moral ground by attempting to make amends for his past misdeeds.

Before looking at these two kinds of attempts to recover lost moral ground in Walt's case, however, two defenses against accusations of moral wrongdoing will first be considered, since Walt also avails of these defenses. The first is the justificatory defense, that of seeking to justify the moral wrongdoing, so that it is no longer morally wrong. The second is the mitigatory defense, that of seeking to excuse the moral wrongdoing, so that the person is no longer responsible for the moral wrongdoing. As will be seen, it is not possible, ultimately,

J.E. Mahon

Lehman College, City University of New York, New York, NY, USA

J. Mahon $(\square)$

NUI Galway, Galway, Ireland

(C) The Author(s) 2017

K.S. Decker et al. (eds.), Philosophy and Breaking Bad,

DOI 10.1007/978-3-319-40343-4_10 
to defend Walt against accusations of moral wrongdoing in either of these two ways, beyond a few cases.

\section{Defending Yourself from Blame}

J.L. Austin famously argued that when you are accused of acting in a way that is wrong, bad, or even just inept, there are two avenues of defense. You may accept full responsibility for the action, but deny that it was wrong, bad, or inept. This is the justification defense. You accept that you performed the action, but you attempt to justify the action by attempting to demonstrate that it was, in fact, the right thing to do. The second route is to agree that the action was wrong, bad, or inept, but to deny that you were responsible-either fully or partially - for the action. This is the excuse defense. You attempt to excuse the action by attempting to reduce or eliminate your responsibility for the action. ${ }^{1}$

In the criminal law, almost every crime may be said to have two elements: the first is the forbidden behavior, known as the actus reus ("guilty act") which can involve failing to do something as well as doing something. The second element is the state of mind of the individual engaging in the behavior, which includes both the knowledge of what one is doing and the choice of doing it; these are known collectively as the mens rea ("guilty mind"). The forbidden behavior must be voluntary in the basic sense that one is in control of one's behavior; one is not, for example, hypnotized, sleepwalking, or drugged. ${ }^{2}$ The required state of mind can vary in degree. It can be intentional, as the crime of murder (killing “with malice aforethought”), such as when Todd Alquist shoots Andrea Cantillo on her front porch within view of Jesse Pinkman ("Granite State"). It can be merely knowing, as in the crime of voluntary manslaughter-for example, killing someone when provoked, such as when Spooge's wife tips the stolen ATM on his head because he is verbally abusing her ("Peekaboo"). It can be merely reckless, as in the crime of (so-called) "involuntary manslaughter," such as running a red light and killing someone crossing the street as a result; something like this could have happened when Walt was running red lights while driving his car out to the Tohajiillee Indian Reservation to save his money from being torched by Jesse ("To'hajiilee"). Or it can be merely negligent, as in the crime of criminally negligent manslaughter, as seems possible in the case of the negligent error made by flight traffic controller Donald Margolis - a result of his depressed state-that led to Wayfarer 515 colliding mid-air with JM 21 over Albuquerque, killing 167 passengers $^{3}$ ("ABQ"). In each case, however, it must be true that the person knew, or should have known, what was happening, and that the person chose, or failed to choose, to act.

Defenses by justification and excuse accept that the person committed the "guilty act" and that the person had the requisite "guilty mind." Nevertheless, they insist that the person is not to be found guilty of criminal or moral wrongdoing. The justification defense says that there is nothing wrong with the 
"guilty act," and that it should not be condemned. The excuse route says that even though there is something wrong with the "guilty act," and even though the person had a "guilty mind," nevertheless, the person should not be condemned.

\section{Justifying or Excusing Your Actions}

The justification defense is more straightforward than the excuse defense. It can be understood in terms of a choice between two evils; that is, the "guilty act" may be performed because it is the lesser of two evils. The idea is that, in the particular situation, it would be a lesser evil to violate the moral rule, or break the law, than it would be to abide by the moral rule or to obey the law. ${ }^{4}$ For example, in Season Three's "One Minute," when Walt's brother-in-law, Drug Enforcement Agency (DEA) agent Hank Schrader, is shot at by Marco and Leonel Salamanca while in his car, he reverses his car into Leonel, severely injuring him, and then shoots Marco as Marco is about to behead him with an axe. Hank's injuring and killing the two assassins (cousins of drug kingpin Tuco Salamanca, whom Hank had killed earlier in a shoot-out in Season Two's "Grilled") was justified because it was in self-defense. There was nothing morally wrong or criminal in what he did. The same can be said of Skyler White slicing Walt's hand with a kitchen knife when she refuses to run from the police with Walt, believing that he may have killed their brother-in-law, Hank ("Ozymandias"). What she did was justified because she was acting in self-defense as well as in defense of her children. There was nothing morally wrong or criminal in what she did. In both cases, Hank and Skyler know full well what they are doing, and choose to so act, but the behavior is permissible and not to be condemned, because it can be said to be a lesser evil to harm an aggressor than to suffer harm from an aggressor. ${ }^{5}$

The excuse defense is more complicated than the justification defense. For behavior to be excused, it must be the case that the person knows or should know what he or she is doing, chooses to act, and yet is not blamable or not as blamable. That is, even though the person has a "guilty mind," nevertheless, he or she is not as morally or legally blameworthy. These cases may be a matter of the person having a diminished capacity: examples include immaturity due to young age, mental illness, or the existence of duress or coercion. ${ }^{6}$ For example, in Season Two's "Mandala," when 10-year-old Tomás Cantillo shoots and kills Christian "Combo" Ortega on orders from the two unnamed drug dealers working for Fring, he is not as morally or legally blameworthy for the killing, because he is merely a child. Or take Season Five's "Granite State," in which Jesse agrees to remain as a prisoner and cook methamphetamine for Jack Welker, after one of the White Supremacists, Todd, kills his former girlfriend, Andrea, and threatens to kill her only remaining son, Brock. In this situation, Jesse is not as morally or legally blameworthy for cooking for the gang because he is being coerced into doing so. 
Although insanity is also a moral and legal excuse, it should be noted that being a homicidal maniac is not a case of insanity. Nor is engaging in anti-social and/or criminal behavior the same as being mentally ill. To quote the Model Penal Code, "the terms 'mental disease or defect' do not include an abnormality manifested only by repeated criminal or otherwise anti-social conduct." ${ }^{7}$ For example, it would not be possible to excuse Tuco from being less blameworthy for his killings on the basis that he is a homicidal maniac, which he clearly is.

\section{“He’ll Kill Your Entire Family If You Let Him Go”}

Given justification or excuse as the two possible avenues of defense, it is difficult to see how Walt could ever avail himself of the latter defense. He is not immature due to young age. He is not insane. He is not suffering from any mental illness. He was not coerced into entering a life of crime and becoming "Heisenberg," the leading manufacturer of crystal meth in the southwest. It is also difficult to see any of the killings he commits as coerced. If anything, Walt may be said to be guilty, morally if not legally, of coercing others into helping him with his life of crime. For example, he only gets small-time drug dealer Jesse to agree to work with him and make crystal meth after he threatens to turn him in to the DEA in the pilot episode.

It may be possible, however, for Walt to avail himself of the justification defense. In "To'hajiilee," when Walt is driving out to the Indian reservation to stop Jesse from burning his buried money, he shouts at Jesse on the cell phone: “Open your eyes. Can't you see that I needed you on my side to kill Gus? I ran over those gang-bangers, I killed Emilio, and Krazy-8. Why? I did all of those things to try to save your life as much as mine. Only you're too stupid to know it." This could be interpreted as Walt claiming that was acting in self-defense, and/or in defense of Jesse, and hence, that his behavior was justified.

In the pilot episode, Walt kills drug-dealer Emilio Koyama, and gravely injures another drug dealer, Domingo Gallardo "Krazy-8" Molina. The two drug dealers had Walt and Jesse at gunpoint, and were about to kill them, but Walt told them that he would show them how to make crystal meth in his makeshift Winnebago lab, in return for their lives being spared. Instead, he adds phosphorous to boiling water, producing a deadly phosphine gas and locks them in the vehicle with the gas. Walt does so because he does not trust the dealers not to kill them once they know how to make crystal meth his way. It is possible to see this killing and injuring as justified because it is a case of self-defense (Walt) and defense of others (Jesse) against aggressors. It is plausible to believe that the drug dealers cannot be trusted to keep their agreement once they know how to make crystal meth Walt's way. ${ }^{8}$ The same could be said of Walt's attempt to poison Tuco with ricin after Tuco kidnaps Walt and Jesse and is holding them hostage until he can transport them to Mexico to cook crystal meth for him ("Grilled). Walt was acting in self-defense, and in defense of an innocent other. 
However, it is more difficult to justify the rest of Walt's behavior in general, and his killings in particular, on the basis of the defense of self and others. His killing of Krazy- 8 fails to be a case of legally justified killing, since Krazy- 8 is not currently a threat, tied up as he is in the basement of Jesse's house (“... And the Bag's in the River"). It would be possible, by contrast, for Walt to turn himself in and have Krazy-8 arrested. Morally, Walt wrestles with his conscience in deciding whether or not to "murder" Krazy-8, citing in his pro and con list many reasons to let him go. However, when he knows that Krazy- 8 is planning to kill him with a shard of a broken plate once he is freed, he kills Krazy- $8 .^{9}$ If this killing — of an admittedly murderous drug-dealer, who cannot be trusted - cannot be morally justified, then Walt's later killings for the sake of protecting his crystal meth empire certainly cannot not be justified.

Even if the killing of Krazy- 8 could be morally justified, it is hard to see how Walt's subsequent killings are morally justified, such as his killing of the two "gang-bangers" in Season Three's "Half Measures." As mentioned in the last section, these two drug dealers, working for Gus Fring, ordered Tomás Cantillo, the son of Jesse's girlfriend, to kill Jesse's friend Combo. After all, Combo was dealing Walt and Jesse's crystal meth on their turf. After Jesse convinced Gus to stop using kids to do his dirty work, Gus's dealers kill Tomás in order to cover their tracks. Enraged, Jesse gets a gun and confronts themeven though they are armed, experienced killers. Before they have a chance to kill Jesse, Walt runs them over in his Pontiac Aztek, killing one instantly. $\mathrm{He}$ then gets out and shoots the other point-blank in the head, shouting at Jesse, "Run!" Neither drug dealer was posing a threat to Jesse-or Walt-before Jesse went after them. Even if Jesse is entirely right to be outraged at their killing of Tomás, his attempt to kill them is a case of revenge-seeking rather than bringing them to justice. Walt does save Jesse from certain death at their hands, but Jesse was in peril only because of his own actions. For that reason, this fails to be a case of defending an innocent person. Walt's own life was never in danger either, and hence this fails to be a case of self-defense. As much as Walt may be motivated by his concern for Jesse's life rather than merely the prospect of losing his partner, and as much as the two drug dealers are beyond doubt ruthless murderers, Walt's killing of them in order to protect Jesse fails to be a case of justified killing, either legally or morally. ${ }^{10}$

It's also worth noting that Walt did not himself kill Gus Fring. Walt provided Gus's mortal enemy, wheelchair-bound Hector “Tio" Salamanca, an opportunity and means to kill Gus. Years before, Salamanca had murdered Gus's original business partner and presumed lover, Max Arciniega, as seen in a flashback in "Hermanos." Walt provides Salamanca with a powerful bomb that allowed him to kill Gus, Gus's assistant, Tyrus Kitt, as well as himself, in Season Four's "Face Off." Nevertheless, it was Walt's idea to convince Hector to kill Gus, and Walt only enlists Hector's help after he fails to kill Gus himself with the bomb. While it is true that Walt believes Gus wishes to kill him sooner or later and to have Jesse take over the lab, nevertheless, Gus is not currently a threat to Walt. Walt has the opportunity to turn himself in to the DEA with the 
rest of his family, inform on Gus, and escape. He chooses not to do so, instead opting to kill Gus with Hector's help. Killing Gus is therefore not a case of selfdefense. It is also not a case of justified killing, either legally or morally. While it is true that "none of the dead were innocent. Salamanca, Gus, and Tyrus are all killers, wrapped up in the drug trade," ening Walt's life, which establishes the relevant meaning of "innocent" when considering whether killing them was justified.

Walt's many other killings - for example, when he lets Jane Margolis, Jesse's girlfriend, choke to death on her own vomit ("Phoenix"), or when he shoots Gus's former hitman, Mike Ehrmantraut ("Say My Name"), or when, with an M60 mounted in the truck of his car, he mows down the White Supremacist gang led by Jack Welker who are holding Jesse prisoner ("Felina") — cannot be classified as cases of defense of self or others either, and hence are not justified killings, either legally or morally. Much as the killing of that gang of murderers might be thought to be a fitting end to their lives and a service to the world, Walt could have freed Jesse and turned them in to the police without killing any of them.

Neither of the two possible defenses-justification or excuse-can, therefore, absolve Walt of his moral blame. If he wishes to escape moral blame, his remaining options are to revise the account of what occurred, so that he is blameless, or to admit wrongdoing and attempt to make up for it.

\section{ReWriting the Past}

Revisionism consists in recovering one's lost moral ground by denying that anything wrong was done. Since one has not wronged anyone, no moral ground has been lost, and there is no moral ground to recover. Walt's efforts to recast his actions in a more honorable light are many and varied, but his last phone call to his son, Walt Jr. ("Granite State"), represents a particularly poignant attempt: "Son, the things that they're saying about me... I did wrong... I made some terrible mistakes... but the reasons were always... things happen that I never intended... I never intended...," he pleads.

Walt offers two different denials that he intended for any of the bad things in his career of crime to happen. Since he did not intend for any of the bad things to happen, he cannot be held guilty of moral wrongdoing. But he also seems to tell Walt Jr. that he had anything except the best reasons for acting in the way that he did, even if he did intend for some or or all of the bad things to happen. Do any of these exculpate him?

Walt could mean, first, that he never imagined that any of the bad things that happened would, in fact, happen, such as the killing of Hank Schrader by Jack Welker, in "To'hajiilee." Such things, he could be saying, were unforeseen by him when he embarked on his journey of manufacturing methamphetamine. If that is what he is claiming, then he is attempting to escape blame by appealing to the idea that he cannot be held responsible for bad things that happen as a result of what he did just in case he never imagined that they would happen. 
He would be embracing the legal and moral standard of requiring a mens rea, and arguing that in order for him to be held liable for such bad things, he must have had a "guilty mind"-something that he denies having.

In embracing the standard of requiring a mens rea, Walt would be rejecting the standard of strict liability, or "faultless" liability, a standard used extremely rarely in the criminal law, and even more rarely (if ever) in morality, in which you are held criminally liable for what happens as a result of what you do (or do not do), even though you lacked any criminal intent, or knowledge of breaking the law, and were not reckless, or even negligent, in your behavior. An example would be getting a minor intoxicated by serving them alcohol, even if you had taken reasonable steps to ensure that they were of legal age. ${ }^{12}$

The simple problem with Walt's attempt to escape blame by denying he had a mens rea-intent, knowledge, recklessness, or negligence-to be held culpable, is that it is simply false that he never imagined any of these bad things could happen. He was fully aware of the risks of people being harmed as a result of what he was doing. As noted above, Walt killed a number of people himself; he also ordered the killing of ten former associates of Mike's in their jail cells. While he could attempt to argue that these killings were not, in fact, wrongful actions, because the victims were murderers, this would be a very different kind of defense (it would be an attempt to justify these killings, as discussed earlier). It would also fail to absolve him from blame for other bad things that he did, such as letting Jane die or ordering Jesse to kill Gale. Neither Jane nor Gale is a murderer. As other commentators have said, "But Walt's ordering Jesse to kill Gale under the threat of Walt's own demise, due to Walt's own actions, makes Walt complicit, and morally guilty for Gale's death perhaps as much as if he had himself pulled the trigger." ${ }^{13}$ And these acts of violence do not even take into account the enormous amount of harm that he knowingly caused by manufacturing and selling the highly addictive and destructive crystal meth to people all over the country.

Walt did indeed possess the requisite mens rea, therefore, to be held culpable for these and many other bad things that happened. Even if it were true that there were some bad things that Walt never could have imagined-such as the deaths of the 167 people aboard flights Wayfarer 515 and JM 21-it is not clear that Walt can be absolved of blame for these, at least morally, on the basis that to hold him responsible would be to hold him to the standard of strict liability. It was Walt who let Jane choke to death on her own vomit, and it was her death that sent her father into a depression, which, it's not unreasonable for us to assume, led to the error and the deaths of the passengers, as well as his subsequent suicide. If this is what happened, then Walt may be held morally responsible for the deaths of those passengers, even if he cannot be held legally responsible, because he did something morally wrong in letting her die, and his moral wrongdoing ultimately led to their deaths. ${ }^{14}$ The same can be said about Hank's death, and that of his partner Steve Gomez, at the hands of Jack Welker and his gang. Hank would never have met up with Jack Welker and his gang in the To'hajiilee Reservation if he had not been chasing Walt to bring 
him into custody for manufacturing and selling crystal meth. Walt does bear the moral responsibility for their deaths, because his decision to make crystal meth, and especially, to continue to make it after so many people were harmed, was morally wrong. As another commentator has said, "For the first time, the reality of what his descent into Heisenberg truly means hits Walt. He collapses, knowing that his deeds finally led to the ultimate sin. A family member is dead because of him." 15

Embracing the standard of requiring a mens rea, therefore, will not absolve Walt of moral blame.

\section{Collateral Damage}

In saying to Walt, Jr., that "things happen that I never intended... I never intended...," Walt could mean something weaker than simply that he lacked the requisite mens rea to be blamed, morally or legally. He could mean that, although he believed either initially or eventually that these bad things would happen, nevertheless, he did not intend that any of these bad things would happen. He could be saying, simply, that he never intended to harm anyonethat he never intended for anyone to get hurt.

If this is what Walt is claiming, then he may be attempting to escape moral blame (if not legal blame) by implicitly appealing to the Doctrine of Double Effect (or the Principle of Double Effect), according to which an action that has both good and bad effects may be morally permissible. According to this doctrine, so long as I am intending some significant good, it is sometimes morally permissible to do something bad as a foreseen side-effect (the double effect), even if it would be morally impermissible to intend that same bad thing. ${ }^{16}$ For example, in fighting a just war, it may be morally permissible to bomb a munitions factory in a nighttime bombing raid, injuring and even killing civilians asleep in their beds near the factory, as a side-effect of the factory bombing (socalled collateral damage), even if it would be morally impermissible to bomb those same civilians for the sake of winning the war. So long as I act in a way that is in itself morally praiseworthy, or at least not morally wrong (blowing up the enemy's munitions factory), only intending the good effect (the destruction of the enemy's arsenal, and ultimately, the defeat of the enemy), and not intending the bad effect, which I nevertheless foresee (injuring and killing nearby civilians), then my action is blameless, and may be praiseworthy. There are a few caveats to this: the bad effect I produce cannot be a means to the good effect (injuring and killing nearby civilians is not a means of destroying the arsenal or defeating the enemy), and the good effect must be sufficiently proportionately good that it compensates for the bad effect (the destruction of the enemy's arsenal, and ultimately, the defeat of the enemy, is sufficiently proportionately good that it compensates for the injuring and killing of nearby civilians). Such a doctrine may be said to be behind, for example, the morally permissible prescription of certain pain-reliving drugs like morphine that 
shorten life expectancy, or the removal of a cancerous womb from a pregnant woman (a hysterectomy), which kills the fetus.

According to some interpretations of the Doctrine of Double Effect, selfdefense (and likewise the defense of innocent others) may be justified in this way: I perform some morally neutral, or morally praiseworthy, action, with the intent to defend myself (a good effect), and I merely foresee harming another person (bad effect). ${ }^{17}$ If this were correct, then it could be argued that, for example, when Walt poisons Emilio Koyama and Krazy-8, his would-be killers, he does something that is morally neutral (mixing compounds and producing a gas) for a good effect (saving his life), and merely foresees their deaths as a result.

But it is highly doubtful that self-defense can ever be justified by appealing to the Doctrine of Double Effect. In self-defense, I do, in fact, intend to harm the other person who is about to harm me: this is the means to saving my life. ${ }^{18}$ Self-defense is justified because you are justified in intending to harm someone who intends to harm you. That other person is a current threat, and not an innocent person. But even if Walt's acts of self-defense can somehow be justified by appealing to this doctrine, there are many other things that Walt does that cannot be justified by appealing to the doctrine. An example is when Walt (presumably) poisons Brock Cantillo- the son of Andrea, Jesse's girlfriendwith enough Lily of the Valley to make him ill, but not enough to kill him, and blames it on Gus Fring. Walt intends to harm an innocent boy (a morally wrong act), as a means to save his own life (a good effect). But intentionally committing a morally wrong act, even for a good end, is completely prohibited by the Doctrine of Double Effect. Walt cannot avoid blame for poisoning Brock Cantillo by appealing to this doctrine. The same can be said about Walt's ordering Jesse to kill Gale. Even if Walt believed that Gus was going to replace him with Gale and kill him, Gale himself was innocent. Walt intended to harm an innocent person (a morally wrong act), as a means of saving his own life (a good effect), something completely prohibited by the Doctrine of Double Effect. None of this can be considered collateral damage.

This is even more true with respect to Walt's making and selling of crystal meth. Walt produces very large quantities of an illegal, highly addictive substance for which there is a huge commercial demand. He does so, as he says, to provide for his family, and to cover his expenses for his cancer treatment. But the good effects of making large profits don't remotely compensate for the bad effects of the distribution and sale of crystal meth over a vast territory by criminal gangs. Moreover, those good effects could have been achieved by other means, had Walt been prepared to swallow his pride and accept the money offered by his fabulously rich former partner, Elliott Schwartz, and Walt's former girlfriend (now Elliott's wife) Gretchen Schwartz.

Appealing to the Doctrine of Double Effect, therefore, will not allow Walt to escape moral blame. 


\section{For Good Reasons}

There is a third way of understanding what Walt is saying to Walt, Jr. when he says, "I never intended..." He might be restating his previous claim that "I did wrong... I made some terrible mistakes... but the reasons were always..." If this last sentence is finished with "good," then Walt would be admitting that he acted in morally wrong ways, but for good reasons- he had good intentions. Here it is important to note that the word "intention" is ambiguous. It can mean both why Walt does what he does-the end or goal for which he acts - as well as what Walt does. The first meaning of intention (as in claiming that someone acted with good intentions) is equivalent to the reason or motive for doing something; the second meaning (as in claiming that it was someone's intention to do this rather than that) is equivalent to the (intentional) action itself. ${ }^{19}$ It is the first meaning that is relevant here. ${ }^{20}$ Understood in this way, Walt is attempting to reduce or eliminate his blameworthiness for what he has done by saying that his reasons or motives for acting were always good. As he says in Season Three's "I.F.T.": "I've done a terrible thing, but I've done it for a good reason. I did it for us."

This is by far the weakest way for Walt to attempt to escape moral blame. To begin with, it would not absolve him from any blame in the eyes of the law. Granted that a person knows what he is doing (that is, has the requisite mens rea), and granted that he or she is not mentally ill or under duress, the reason or motive behind someone's criminal behavior is completely irrelevant: "Hardly any part of penal law is more definitely settled than that motive is irrelevant." ${ }^{21}$ If a person intentionally kills another who is not a current threat to him-that is, if he commits murder - then it is irrelevant, as far as the law is concerned, if he murdered the person for revenge, for money, as a dare, to impress a girlfriend, for fun, to save himself, or to save other people. ${ }^{22}$ For Walt to argue that, although he intentionally did things that were wrong, he did them for good reasons, is simply for him to argue that he is not a bad person despite the bad things that he has done.

Right up until the day he dies, Walt repeatedly tells his wife Skyler that the reason for all his actions - the reason why he manufactured crystal meth, protected and sold his product, and ultimately killed and harmed various people who got in the way-was to make enough money to take care of his family since he was going to die from cancer. This is what Walt means when he says to Walt, Jr., "but the reasons were always [good]." Indeed, when Walt begins to have scruples about his breaking bad and its fallout, he is talked back into staying the course by Gus, on this very basis, in Season Three's "Más":

Gus: Why did you make these decisions?

Walt: For the good of my family.

Gus: Then they weren't bad decisions.

Gus: What does a man do, Walter? A man provides for his family.

Walt: This costs me my family. 
Gus: When you have children, you always have family. They will always be your priority, your responsibility. And a man... a man provides. And he does it even when he's not appreciated, or respected, or even loved. He simply bears up and he does it, because he's a man.

The problem with this attempt to avoid blame, however, is that on the day that he dies, Walt finally admits that taking care of his family was not his reason. As he says in his final exchange with Skyler, he did it for himself:

Walt: You have to understand...

Skyler: If I have to hear, one more time, that you did this for the family-.

Walt: I did it for me.

Skyler: [Looking surprised].

Walt: I liked it. I was good at it. And... I was... really... I was alive.

Although it may be possible to reduce or eliminate Walt's moral blameworthiness for what he did by establishing that he did it all selflessly, in order to take care of his family, it is hardly possible to reduce or eliminate his moral blameworthiness by claiming that he did it all because it made him feel alive.

Given that none of the three possible revisionist avenues for Walt will work, he cannot exonerate himself by availing of this approach to moral wrongdoing. Walt's repeated attempts to rewrite (and stage-manage the rewriting) the script of what has happened cuts no ice. There is lost moral ground to recover, a great deal of it. It follows that Walt has no option, in seeking redemption, other than attempting to make amends for his wrongful behavior.

Before considering this final option, however, it is worthwhile to address the question raised by Walt's final admission that his motivation was self-interest. Was he lying to Skyler, and Walt Jr., and Jesse, all along? Or was he deceiving himself?23

\section{In DeNIAL}

The best explanation of why Walt never previously admitted his true reason for pursuing a career as a drug kingpin is that he could not even admit it to himself. Quite simply, he was in denial about his own motivation. Walt's capacity for self-deception is almost as impressive as his capacity for deceiving others. Throughout his short-lived criminal career, he refused to morally evaluate his actions in a negative way or to acknowledge his true motivation, despite accumulating plenty of evidence to the contrary.

In the pilot episode, Walt frames his denial unequivocally. He declares in his speech to his family for the video-recorder: "No matter how it may look, I had only you in my heart." Accused by his wife of being a drug dealer in "No Más," he replies "I'm a manufacturer, not a dealer...." "I am not a criminal, that is not me," he tells Gus Fring in the same episode. "I can't be the bad guy," he repeats in the subsequent episode, "Caballo Sin Nombre." He acknowledges 
having made "a series of very bad decisions" ("Más"). "I never saw this coming," he blurts out in the episode "One Minute." "Sometimes compromises have to be made, for the best reasons," we are told in "Half Measures." In Season Four's "Box Cutter," he asserts "I didn't want any of this to happen," and in "Bullet Points," he reminds his wife that "I was and am providing for my family." "I alone should suffer the consequences of those choices," he maintains in the episode "End Times." "What we do we do for good reasons; there's nothing to worry about," he advises Jesse in Season Five's "Live Free or Die." "Now that we're in control, no one else gets hurt," he continues. "I'm sorry about Brock," he says to Jesse in "To'hajiilee," "but he's alive, isn't he?" As he might have said, Walt did make mistakes, but he never did anything wrong.

Walt is, then, in denial, or as Jean-Paul Sartre would say, he is guilty of bad faith. ${ }^{24}$ It beggars belief that someone who arguably understands the chemistry and manufacture of methamphetamine better than anyone else alive could have no understanding of its impact on the bodies and minds of those who consume it. Walt is not ignorant of the ravages of drug addiction. When he goes searching for Jesse, following the death of Jane, he locates him in a fetid, squalid drug den strewn with lacerated, semi-comatose bodies. He even refers to the downstairs of Jesse's house, following a drug party, as "Skid Row." He is also not oblivious to the modus operandi of the drug cartels and the criminal underworld. Nor can Walt claim to be ignorant of the effects that his criminal career has on his family and associates, not to mention the people he kills and orders to be killed. Nevertheless, Walt somehow manages-or chooses-to ignore all of this. Although Sartre allows that to practice bad faith is to "to lie to oneself," he insists that "we distinguish the lie to oneself from lying in general." ${ }^{25}$ In lying to others, I intend to deceive them, that is, to get them to hold as true what I know or believe to be false. But in lying to myself, the person who deceives and the person who is deceived are one and the same; this means, Sartre says, "that I must know in my capacity as deceiver the truth which is hidden from me in my capacity as the one deceived." ${ }^{26}$ Bad faith or lying to oneself is not a state. It is not something that befalls you. On the contrary, "consciousness affects itself with bad faith. There must be an original intention and a project of bad faith." ${ }^{27}$ Sartre concludes that it is a project rather than a condition or a state because the self-deceiver "must know the truth very exactly in order to conceal it more carefully." 28

What is interesting about Walt's particular form of self-deception is that it takes the form of professionalism about his illegal drug manufacturing. This assumption of professionalism clouds his judgment from the very outset and remains embedded in his psyche. It is captured in the refrain that what he does is "just chemistry." Jesse knows "the business," while Walt knows "the chemistry." Walt is in charge of the cooking, because the chemistry is his realm. $\mathrm{He}$ even refuses to accept the accolade of its being art. After his first cook in the pilot episode, Jesse exclaims "You're a goddamn artist. This is art, Mr. White!" Walt replies, "Actually, it's just basic chemistry, but thank you, Jesse, I'm glad 
its acceptable." (Indeed, drug-dealer Emilio, whom he later strangles to death, also calls Walt an artist when he meets him). The chemistry, however, that Walt practices is state-of-the-art: "We will produce a chemically pure and stable product that performs as advertised." Above all, Walt insists, "the chemistry must be respected!" But Walt does more than rigidly respect the chemistry. $\mathrm{He}$ also produces and arranges for the distribution and sale of a substance which, when "burned," will turn so many users into zombies. He kills people to maintain his growing empire, despite having made more money than his family could possibly need. He has been seduced by the charms of professionalism, and this, in part, is what enables him to endure.

Walt's self-deception is also facilitated by Gale, who works as his assistant in the lab. Gale supplies Walt with, as he calls it, a "libertarian" justification for his breaking bad. Not everything that constitutes crime deserves to be criminalized, he asserts in Season Three's "Sunset": "There's crime, and then there's crime, I suppose." As Gale sees it, they supply goods for a market, and if they didn't supply them, someone else would. Moreover, the product they supply contains no toxins or adulterants. Their customers are getting exactly what they paid for. These same customers are consenting adults, deciding for themselves what to do with their lives, and "consenting adults want what they want." So, as producers and suppliers, Walt, Gale, and Gus are expanding the realm of freedom, the range of choices available to adult individuals. They are also fulfilling their contractual obligations. After that, what befalls drugs users is their own fate. They bring it on themselves. As free agents, they could always turn their backs and walk away. But Gale conveniently ignores the fact that their product is highly addictive, thus severely limiting, and perhaps even erasing, the libertarian freedom he speaks of. He also ignores the fact that the distribution and sale of that same product is illegal, and that the state does not condone these kinds of consensual activities.

While Walt's self-deception can be explained, it cannot be defended. The consequences of drug addiction are foreseeable and well documented. As a gifted chemist, Walt is in a prime position to know what these consequences would be for his customers. His involvement in the drug trade, from his encounters with Emilio and Krazy-8, not to mention Tuco, to Gus, and his dealers, exposed him to the ruthless, homicidal behavior commonplace throughout the criminal underworld. Even if he could not have known in advance who would be killed, or when, or where, or how, he could not have been blind to the fact that these things happen, and he knew from the start just how nasty they could be.

\section{Reflections on the Guillotine}

The French existentialist author Albert Camus favored life imprisonment with hard labor over capital punishment for even the very worst murderers. He believed that imposing the death penalty on a person deprived her of the opportunity of making amends, and no one should be denied the opportunity of making amends. In the closing stages of his essay on the death penalty, 
"Reflections on the Guillotine," Camus is concerned with the fate of those he calls "major criminals whom all juries would condemn at any time and in any place whatever. Their crimes are not open to doubt, and the evidence brought by the accusation is confirmed by the confessions of the defense." ${ }^{29}$ He gives the example of a young man who, annoyed by a remark made by his father about his coming home late, killed both his parents in cold blood with an axe, then "undressed, hid his bloodstained trousers in the closet, went to make a call on the family of his fiancée, without showing any signs, then returned home and notified the police that he had just found his parents murdered." 30 While his "odd indifference" was abnormal, his reasoning power remained untouched, and the medical experts asserted he was responsible for his actions, as opposed to concluding he was suffering from a mental illness or acting under duress.

Such "monsters," notes Camus, evoke the most extreme response from society's guardians: “Apparently the nature or the magnitude of their crimes allows no room for imagining that they can ever repent or reform. They must merely be kept from doing it again, and there is no other solution but to eliminate them." Camus, for his part, begs to differ. Everyone, he holds, is capable of making amends, and not just those with a beneficent disposition: "Deciding that a man must have the definitive punishment imposed on him is tantamount to deciding that a man has no chance of making amends." 32

There are two parts to Camus' argument here. First, there is the claim that everyone is capable of making amends. Second, there is the claim that everyone has amends to make. The latter proposition is true because "we have all done wrong in our lives even if that wrong, without falling within the jurisdiction of the law, went as far as the unknown crime." 33 To make sure that we do not miss or underestimate the importance of this point, Camus adds, provocatively, "There are no just people - merely hearts more or less lacking in justice." 34 Allowing even the worst criminal to continue living is, for Camus, essentially a matter of giving precedence to the principle of equality: it is giving him, or her, the same opportunity to make amends as is given to everyone else. So it comes about that "the lowest of criminals and the most upright of judges meet side by side, equally wretched in their solidarity. Without that right, moral life is utterly impossible." 35

Camus has a more abstract and complex concept of making amends than that found in common usage. To make amends, as the phrase is commonly used, means to restore to another, or to others, what you have taken from them; alternatively, it means to compensate others for the harm you have caused them. But for Camus, it means adding good things to the sum of good things you have done, which in turn augments the universal sum of good things done, which in turn will help atone or compensate for all the bad things you have done: "Living at least allows us to discover this and to add to the sum of our actions a little of the good that will make up in part for the evil we have added to the world. Such a right to live, which allows a chance to make amends, is the natural right of every man, even the worst men." ${ }^{36}$ Whereas in common usage making amends means restoring to other people, or compensating them, for 
Camus it means restoring an equilibrium between aggregates of good and evil. Thus, even Camus's preferred alternative to capital punishment-life imprisonment with hard labor - is capable of providing a person with the opportunity to exercise his or her right to atone, since, even under the gruesome conditions of penal servitude during the postwar period, a prisoner could have behaved badly or well toward other prisoners and warders. In any event, Walt, by contrast with Camus's prisoner, manifestly does have the resources to make some reparation to some of those he has harmed, as well as to the wider society.

\section{Making Amends}

Walt, who has been characterized as "a hapless passive-aggressive chemistry teacher" who mutates into "a hapless passive-aggressive meth cook," 37 has also been characterized as a chemistry teacher who has not just broken bad, but "broken evil" - just as evil, indeed, as Gus Fring-and as someone who has "taken his wife down this path too, corrupting her, involving her in a conspiracy, and endangering his family and friends," 38 not to mention converting his partner Jesse into a murderer. Walt has a lot of moral ground to recover. The question is whether and how much of this moral ground can be recovered by making amends for past wrongdoing, in Camus' sense.

It is conceded here that Walt does make some amends for his past misdeeds. The good things that he does in his final days, as depicted in the series' final episode, "Felina," add to the universal sum of good things achieved by all human agents. Walt himself believed he could make amends by way of direct compensation. He rescues Jesse from his imprisonment at the hands of Jack Welker and his gang, ending their crystal meth production, and in so doing removes the remaining threat to his family. He even hands Jesse a gun to give him the opportunity to kill him for all that he had put him through. He devises an elaborate benefaction scheme to finance Walt, Jr.'s college education with $\$ 9.72$ million that he gives to Elliott and Gretchen Schwartz, so that they can set up an irrevocable trust fund for Walt Jr. on his eighteenth birthday. He also supplies Skyler with the GPS coordinates of the place where Hank and his partner Steve Gomez are buried, and tells her "Now you trade that for a deal with the Prosecutor. You'll get yourself out of this, Skyler."

It is true that, in order to do all of this, he has to shoot almost the entire gang-leaving Jesse to strangle his captor and tormentor, Todd-as well as poison Lydia, the mastermind behind the global distribution network for the blue crystal meth. He does not turn them into the authorities. He does not afford any of these murderers the opportunity for moral redemption. Nevertheless, even if these killings cannot be morally justified, the motivation behind wiping out a white supremacist gang, and shutting down global distribution network for the blue crystal meth, as well as that behind saving Jesse and protecting his family is more admirable than simply eliminating the competition. His killings could even be said to add to the sum of good in the world, even if his actions cannot be morally justified. 
It has been said that "More importantly, there is no redemption for Walt in 'Felina.' None of what he does in that final episode excuses what he did in the 61 prior. None of it made him a hero in the end. He does not make up for his lies and crimes. He does not wash away poisoning children and destroying families and being a vile manipulator of people he claimed to care about." ${ }^{39}$ While it is true that Walt's final actions do not excuse his previous moral wrongdoing, and do not elide his previous sins, and while it is true that these final actions do not "make up" for all his crimes and mistreatment of people, nevertheless, it is possible to believe that Walt does make some amends in his final days, and that in general he is right to think that it is possible for moral wrongdoers to recover lost moral ground. To some extent, Walt does recover lost moral ground toward the end of Breaking Bad. How much moral ground he has recovered is a probably a moot point. Suffice it to say that in the concluding scenes Walt appears a sad, depleted, ashen, forlorn, tragic figure, but he is no "monster." Some moral reputation has been restored.

\section{Notes}

1. J. L. Austin, "A Plea for Excuses: The Presidential Address," Proceedings of the Aristotelian Society 57 (1957): 1-30.

2. See Mark C. Murphy, Philosophy of Law: The Fundamentals (Oxford: Blackwell, 2007), 113f.

3. For more on the prosecution of air traffic controllers for criminal negligence and negligent homicide, see Sofia Michaelides-Mateou and Andreas Mateou, Flying in the Face of Criminalization: The Safety Implications of Prosecuting Aviation Professionals for Accidents (Farnham, Surrey: Ashgate, 2010).

4. Murphy, Philosophy of Law: The Fundamentals, 133-134. See also Larry A. Alexander, "Lesser Evils: A Closer Look at Paradigmatic Justification," Law and Philosophy 24 (2005): 611-643.

5. Harming and killing in self-defense is morally and legally permissible, but not obligatory. One could permissibly choose to allow oneself to be harmed or killed by an aggressor, rather than harm an aggressor. It is a further question as to whether harming and killing in order to save (innocent) others is ever morally (and even legally) obligatory, such that it would be morally (and even legally) impermissible to refuse to harm or kill aggressors. For the argument that there is a "moral obligation to kill or seriously harm in defense of others," see James P. Sterba, "Introduction: Justice for Here and Now," in Social and Political Philosophy: Contemporary Perspectives, ed. James P. Sterba (London: Routledge, 2001), 22.

6. Murphy, Philosophy of Law: The Fundamentals, 139.

7. Quoted in Murphy, Philosophy of Law: The Fundamentals, 138.

8. David R. Koepsell and Vanessa Gonzalez have said that "Killing in self-defense is a well-known and widely recognized legal and moral justification or excuse" and "Killing Emilio would have likely been seen as justified or excusable legally" ("Walt's Rap Sheet," in Breaking Bad and Philosophy, ed. David R. Koepsell and Robert Arp (LaSalle, IL: Open Court, 2012), 6-7. However, self-defense is never an excuse. It is only a justification. 
9. Eric San Juan has said "Walt eventually kills the remaining dealer, but only out of self-defense," in Breaking Down Breaking Bad: Unpeeling the Layers of Television's Greatest Drama (Eric San Juan, 2013), 15. But it is not self-defense if the other person is not currently aggressing. Pre-emptively killing Krazy-8, because he knows that Krazy- 8 will attempt to kill him if he releases him, is not self-defense. Perhaps, however, San Juan is only referring to the final struggle, in which Krazy-8 is attempting to stab Walt with the shard of broken plate. Koepsell and Gonzalez have written about the final struggle that "Arguably, Walt's actions now amount to valid self-defense, but his moral blameworthiness for killing Krazy-8 seems greater than for Emilio" ("Walt's Rap Sheet," 6).

10. Koepsell and Gonzalez ask about this case "Is [Walt's] killing of two noninnocents to prevent the death of another non-innocent justifiable? Jesse surely wouldn't have been in the position of weighing to murder Gus but for Walt, so Walt's own actions and intentions are partly responsible for Jesse's intent to murder, and thus his targeting for murder... because Walt himself has helped create the situation Jesse is in, his saving Jesse is perhaps morally justifiable based on Walt's active responsibility, and given their special relationship and Walt's relatively honorable intentions" ("Walt's Rap Sheet," 10). Even if Walt feels partly responsible for Jesse's targeting of the two drug dealers, however, this only goes some way toward explaining why Walt kills them. It does not justify his killing them.

11. Koepsell and Gonzalez, "Walt's Rap Sheet," 12.

12. Murphy, Philosophy of Law, 143 n. 1 .

13. Koepsell and Gonzalez, "Gus's Rap Sheet," 12.

14. Koepsell and Gonzalez have said that "it's a stretch to hold Walt morally responsible for these deaths. Although his actions are complexly implicated in the two related events of the Wayfarer crash and Donald's suicide, and some of Walt's decisions helped lead to them, they seem far too remote to blame upon Walt. He's a cause, but not the proximate or immediate cause of these deaths. His actions and decisions created their possibility, but did not make them inevitable" ("Walt's Rap Sheet," 13-14). However, moral responsibility does not require that one be a proximate cause, as is the case with legal responsibility in tort law. One may be held morally responsible for remote bad things if they happen as a result of one doing something morally wrong.

15. Eric San Juan, Breaking Down Breaking Bad, 88.

16. For the official Catholic Church account of the doctrine, see F. J. Connell, "Double Effect, Principle of," New Catholic Encyclopedia, vol. 4 (New York, NY: McGraw-Hill, 1967), 1021.

17. See Thomas Aquinas on self-defense in Alison McIntyre, "Doctrine of Double Effect," Stanford Encyclopedia of Philosophy, last modified September 23, 2014. Web.

18. For this reason, it seems, Augustine held that self-defense was never justified. See McIntyre, "Doctrine of Double Effect."

19. See James Edwin Mahon, "Doing the Wrong Thing for a Good Reason," in The Good Wife and Philosophy, eds. Kimberly Baltzer-Jaray and Robert Arp (LaSalle, IL: Open Court, 2013), 89-99.

20. When Koepsell and Gonzalez talk about "Walt's relatively honorable intentions" ("Gus's Rap Sheet, "10), and when Eric San Juan says "Skyler gave the money to Ted Beneke. She did so with the best of intentions" (Breaking Down 
Breaking Bad, 59), they are all using "intention" in the sense of reason or motive.

21. Hall, 1960, quoted in Whitley R. P. Kayfman, "Motive, Intention, and Morality in the Criminal Law," Criminal Justice Review 28 (2003): 317-335.

22. In the famous British case of The Queen v. Dudley and Stephens (1884), it did not matter that the two shipwrecked sailors, Tom Dudley and Edwin Stephens, who were in the lifeboat with the sick cabin boy, Richard Parker, were starving to death, and that they killed and ate Parker, and shared the flesh with a third sailor, in order to survive. They were both convicted of murder. See Neil Hanson, The Custom of the Sea: A Shocking True Tale of Shipwreck, Murder, and the Last Taboo (New York, NY: John Wiley \& Sons, 1999).

23. As Eric San Juan has pointed out, “It's a testament to Walter's amazing ability to lie (and Bryan Cranston's amazing ability to deliver those lines) that even in the final week of the show many viewers still believed he was motivated by a desire to provide for his family, even though it was clear that he liked indulging in crime" (Breaking Down Breaking Bad, 84).

24. See Jean-Paul Sartre, Being and Nothingness, trans. Hazel Barnes (London: Methuen, 1958), 47-70, and Existentialism and Humanism, trans. Philip Mairet (London: Methuen, 1965), 30-31.

25. Sartre, Being and Nothingness, 48.

26. Ibid., 48 .

27. Ibid., 49 .

28. Ibid.

29. Albert Camus, "Reflections on the Guillotine," in Resistance, Rebellion, and Death (New York, NY: Vintage, 1995), 218.

30. Ibid., 219.

31. Ibid., 219.

32. Ibid., 220.

33. Ibid., 221.

34. Ibid.

35. Ibid.

36. Ibid.

37. Dan Miori, "Was Skyler's Intervention Ethical? Hell, It Shouldn't Even Be Legal," in Breaking Bad and Philosophy, 27.

38. Koepsell and Gonzalez "Walt's Rap Sheet," 14.

39. Eric San Juan, Breaking Down Breaking Bad, 99. 